\author{
Dominika Maśkiewicz* \\ ORCID: 0000-0002-9276-8708 \\ Uniwersytet Wrocławski
}

DOI: $10.19195 / 1733-5779.27 .7$

\title{
Brak zainteresowania źródłem pochodzenia towaru jako przesłanka podważająca należytą staranność podatnika - glosa do wyroku Wojewódzkiego Sądu Administracyjnego z siedzibą w Opolu, z dnia 27 stycznia 2017 r., o sygnaturze I SA/Op 428/16
}

JEL Classification: K 340

Słowa kluczowe: dobra wiara podatnika, należyta staranność, nadużycie, weryfikacja kontrahenta, obrót olejem rzepakowym

Keywords: good faith of the taxpayer, due diligence, abuse, verification of the contractor, trade in rapeseed oil

Abstrakt: Glosowane orzeczenie dotyczy przesłanek przyznania dobrej wiary podatnikowi biorącemu udział w transakcjach, w których zachodzi prawdopodobieństwo nadużycia podatku VAT oraz zakresu szczegółowości kontroli, jakiej podatnik musi poddać swojego kontrahenta. Wątpliwości budzi przywołana przez sąd przesłanka niezainteresowania źródłem pochodzenia towaru, a także teza, że to właśnie w interesie podatnika leży jak najdokładniejsza weryfikacja kontrahenta. Oba zagadnienia są w niniejszej glosie ponownie rozważane z przytoczeniem doktryny i orzecznictwa sądów krajowych oraz TSUE.

Lack of interest in the origin of the goods as a premise undermining the due diligence of the taxpayer - commentary on the verdict of the Provincial Administrative Court, seat in Opole, of 27th January 2017, on the signature I SA/Op 428/16

Abstract: Commented judgement concerns the conditions for granting good faith to a taxpayer participation in transactions where there is a likelihood of VAT fraud and the level of detail of control that a taxpayer must submit to his contractor. Doubts arouse the court's motive of not being interested

* Opiekun naukowy (Scientific Tutor) — dr hab. Paweł Borszowski prof. nadzw. UWr 
in the origin of the goods, as well as the thesis that it is in the taxpayer's interest to verify the contractor as accurately as possible. Both issues are reconsidered in this opinion with the citation of the doctrine and the jurisprudence of national courts and the Court of Justice of the European Union.

\section{Teza}

Nie ma ustawowego obowiązku, który określałby, jak dokładnie należy zweryfikować drugą stronę transakcji. Strona powinna jednak zdawać sobie sprawę, że to w jej interesie leży, aby ta weryfikacja była jak najbardziej szczegółowa.

Należytą staranność podatnika mogą podważyć: brak legitymowania kontrahenta, zbyt daleko idąca ufność w stosunku do kontrahenta, brak zainteresowania źródłem pochodzenia towaru, brak podwyższonej staranności przy transakcjach podwyższonego ryzyka, na przykład obrotu paliwem ${ }^{1}$.

\section{Stan faktyczny}

Spółka, której przedmiotem działalności był między innymi olej rzepakowy,

w złożonych za poszczególne miesiące 2013 roku deklaracjach VAT-7 wykazała m.in. nadwyżki podatku naliczonego nad należnym [...]. W wyniku postępowania kontrolnego przeprowadzonego w zakresie rzetelności deklarowanych podstaw opodatkowania oraz prawidłowości obliczania i wpłacania podatku od towarów i usług [...] organ I instancji stwierdził, że Spółka wykazała w deklaracjach VAT-7 [...] podatek naliczony do odliczenia [...] wynikający z faktur niedokumentujących faktycznie dokonanych transakcji zakupu, co skutkowało naruszeniem art. 88 ust. 3a pkt 4 lit ustawy z dnia 11 marca 2004 r. o podatku od towarów i usług

— dalej zwanej ustawą o VAT - a w konsekwencji zawyżeniem kwot wykazanych do zwrotu na rachunek bankowy. Ponadto organ wskazał, że spółka ,przy dołożeniu minimum staranności rzetelnego kupca, powinna mieć świadomość, że zawiera transakcje z nierzetelnymi firmami, tak zwanymi słupami”. Wydając swoją decyzję, organ podkreślił, że za przyjęciem takiego stanowiska przemawia także brak zainteresowania ze strony spółki pochodzeniem tego towaru oraz jego późniejszym przeznaczeniem w obrocie gospodarczym podczas jego dalszej odsprzedaży. W wyniku wnikliwie przeprowadzonego postępowania dowodowego organ zarzucił prezesowi spółki świadome uczestniczenie w tak zwanym obrocie karuzelowym z innymi podmiotami, którego celem było wyłudzanie podatku VAT, jak również uchylanie się od odprowadzania należnego podatku VAT.

W odwołaniu od powyższej decyzji spółka wniosła o jej uchylenie w całości, zarzucając między innymi błędy w ustaleniach faktycznych poczynionych przez organ, według których prezes zarządu spółki „wiedział, lub co najmniej miał podstawy, aby wnioskować o nierzetelności" swoich kontrahentów, a także nie dochował należytej staranności w kwestii wiarygodności wspomnianych podmiotów. Odpowiadając na niewłaściwe, zdaniem skarżącej spółki, ustalenia co do

\footnotetext{
1 Wszystkie cytaty pochądzą z Legalis nr 1600789.
} 
stanu faktycznego, jak również samych intencji prezesa spółki, wyjaśniono, że nie był on zainteresowany źródłem pochodzenia towaru, a jedynie jego jakością oraz ceną, co wynika z charakteru obrotu gospodarczego. Podkreślono, że „,w warunkach rynkowych normalnym jest, że nabywca nie zna producenta ani dalszego przeznaczenia towaru".

Po rozpoznaniu sprawy przez organ II instancji Wojewódzki Sąd Administracyjny (WSA) w Opolu wyrokiem oddalił skargę,

odnosząc się do [...] kwestii, iż nie zostało udowodnione, że strona świadomie i celowo brała udział $\mathrm{w}$ oszustwie podatkowym. Sąd podziela w tym zakresie stanowisko organów podatkowych, zdaniem których skarżąca powinna przynajmniej przypuszczać, że bierze udział w transakcjach, które mogą wiązać się z działaniem przestępczym oraz mogła dochować należytej staranności celem zabezpieczenia się przed oszustwem, ale tego nie uczyniła.

WSA zaznaczył, że zgodnie z orzecznictwem Trybunału Sprawiedliwości Unii Europejskiej (TSUE) niewątpliwie wynika, ,że przesłanką wystarczającą do pozbawienia podatnika prawa do odliczenia podatku naliczonego jest nie tylko świadome uczestnictwo w oszustwie podatkowym, ale także brak należytej staranności”. A zatem, jak wywodził WSA, chodzi o takie podmioty, które ,wiedziały lub na podstawie obiektywnych okoliczności istniejących w sprawie powinny były wiedzieć, że nabywając towar uczestniczyły w transakcji wykorzystanej do popełnienia oszustwa w podatku VAT". Zdaniem Sądu przesłanki, które zostały wskazane w tezie wyroku, będące warunkami uznania dobrej wiary podatnika, nie były dopełnione przez prezesa spółki. W wyroku zwrócono uwagę między innymi na brak zainteresowania źródłem pochodzenia i przeznaczenia towaru w łańcuchu firm, co identyfikuje spółkę jako nierzetelnego podatnika.

\section{Glosa}

\section{Uwagi ogólne}

Pomimo zasadności wydanego wyroku, należy poddać go częściowej krytyce, ze względu na dwie poruszone przez Sąd kwestie. Na aprobatę nie zasługuje pierwsza przytoczona teza, w której wskazuje się, że to w interesie podatnika leży jak najbardziej szczegółowe przeprowadzenie weryfikacji kontrahenta. Nie można w pełni zgodzić się także z drugą tezą — kryterium braku zainteresowania pochodzeniem towaru, które jako przesłanka do oceny należytej staranności kontrahenta wymaga ponownego zdefiniowania.

Glosowany wyrok wydaje się obecnie szczególnie istotny, ponieważ dotyka kwestii o kluczowym znaczeniu dla podmiotów gospodarczych — warunków, które decydują o działaniu w dobrej wierze przez podatnika w wypadku, gdy dojdzie do nadużycia w podatku VAT. W orzecznictwie TSUE jako nadużycie prawa wskazuje się takie zachowania podatników, ,które nie stanowią działań naruszających przepisy prawa w sferze prawa prywatnego ani podatkowego, lecz prowadzą 
do sytuacji, które nie są uważane przez organy podatkowe za prawidłowe zastosowanie się podatnika do przepisów prawa podatkowego" ". Precyzyjne określenie tych właśnie przesłanek stanowi z jednej strony pewnego rodzaju zabezpieczenie interesów przedsiębiorcy, któremu — po ich spełnieniu — nie zostanie zarzucony brak należytej staranności w wyborze kontrahenta, a w konsekwencji nie będzie podejrzewany o udział w działaniach kwalifikowanych jako prowadzące do nadużycia podatkowego. $Z$ drugiej zaś strony bardzo ważne jest, aby sądy wydające orzeczenia mogły na podstawie jasnych kryteriów zadecydować o rzetelności lub nierzetelności podmiotów uczestniczących w takich transakcjach. Jest to kwestia tym bardziej fundamentalna, ponieważ szacowane straty poniesione w budżecie z powodu luki w podatku VAT wynoszą co roku od kilkunastu do kilkudziesięciu miliardów złotych. $Z$ tych właśnie powodów przyznawanie podatnikowi statusu, zgodnie z którym dopełnił on należytej staranności, powinno opierać się na obiektywnych i racjonalnych warunkach, zgodnych z charakterem obrotu gospodarczego.

\section{Zakres szczegółowości przy weryfikacji kontrahenta}

Prawo do odliczenia podatku naliczonego w wypadku, gdy organ podatkowy stwierdzi, że doszło do nieprawidłowości, zależy od dobrej wiary oraz należytej staranności podatnika. Mimo że terminy te nie zostały wyrażone w przepisach prawa podatkowego, pojęcie „dobrej wiary” jest akcentowane w poglądach formułowanych w orzecznictwie TSUE. W wielu wyrokach podkreślono, że prawo do odliczenia podatku od towarów i usług może zależeć od istnienia po stronie podatnika dobrej wiary i dołożenia przez niego należytej staranności w związku $\mathrm{z}$ transakcją, a więc kluczowym elementem jest świadomość podatnika ${ }^{3}$. Z powodu braku w prawie podatkowym definicji legalnej tych dwóch pojęć warto rozważyć zasadność zastosowania terminów używanych w prawie cywilnym. Wynika to $\mathrm{z}$ relacji prawa cywilnego i prawa podatkowego, a w efekcie także przenoszenia pewnych terminów. Należy zaznaczyć, że korzystanie z ukształtowanych w prawie cywilnym pojęć „dobra wiara” oraz „należyta staranność” nie jest tendencją ogólną. Zatem w dobrej wierze pozostawałby ten, kto nie zna z przyczyn usprawiedliwionych niekorzystnego dla niego stanu prawnego; natomiast jako należytą staranność należałoby uznać — w odniesieniu do dłużników-przedsiębiorców — ogólnie wymagane zachowanie określane przy uwzględnieniu zawodowego charakteru ich działalności ${ }^{4}$. Brak określonej definicji, która nakładałaby na podat-

2 A. Zalasiński, Koncepcja nadużycia podatkowego w unijnym prawie podatkowym - potencjalne kierunki oddziatywania na prawo polskie, [w:] 5 lat doświadczeń w polskim prawie finansowym, red. H. Litwińczuk, Warszawa 2010, s. 441.

3 Wyrok TSUE z 22 listopada 2015 r., C-277/14 PPUH Stehcemp sp.j. Florian Stefanek, Janina Stefanek, Jarosław Stefanek przeciwko Dyrektorowi Izby Skarbowej w Łodzi.

${ }^{4}$ W. Kotowski et al., Przestępstwa karuzelowe i inne oszustwa w VAT, red. I. Ożóg, Warszawa 2017, s. 39. 
nika obowiązek podjęcia konkretnych czynności zmierzających do weryfikacji kontrahenta, nie może skutkować nałożeniem na podatnika obowiązków niewyrażonych w ustawie, których niedopełnienie rodziłoby tak poważne konsekwencje jak odebranie prawa do odliczenia podatku. W związku z niewyrażeniem owych obowiązków w ustawie powinny być one traktowane w sposób ogólny, a zatem oczekiwana weryfikacja nie powinna być — odmiennie od tego, co wskazał WSA w pierwszej tezie - , jak najbardziej szczegółowa”. Aby jednak w pełni stworzyć wzorzec należytej staranności - poza ewentualnymi definicjami z kodeksu cywilnego — należy również uwzględnić bogate orzecznictwo Trybunału Sprawiedliwości Unii Europejskiej w tym zakresie. W uzasadnieniu glosowanego wyroku Sąd wskazuje, że między stronami nie ma sporu co do faktu, że brakuje przepisu ustawowego, który wskazywałby, jak dogłębnie należy zweryfikować drugą stronę transakcji, natomiast ,skarżąca powinna sobie zdawać jednak sprawę, że to w jej interesie leży, by ta weryfikacja była jak najbardziej szczegółowa". Ten pogląd wskazany przez WSA nie znajduje odzwierciedlenia w orzeczeniach TSUE. Zdaniem Trybunału podatnik dokonuje oceny kontrahentów w interesie publicznym, ,wbrew intuicji artykułowanej między innymi przez organy podatkowe, że działa we własnym dobrze pojętym interesie, aby móc odliczyć podatek naliczony" . Za słuszne należy przyjąć rozważania Trybunału, że weryfikacja kontrahenta pod kątem jego udziału w oszustwie podatkowym wkracza w sferę ocen zastrzeżonych dla organów państwa, a tym samym jest to bardzo daleko idące oczekiwanie stawiane przed podatnikiem, które wykracza poza obszar realnie wykonywanego zobowiązania. Glosowany wyrok WSA w Opolu nie odpowiada linii orzeczniczej proponowanej w wyrokach TSUE.

Zasada należytej staranności i dobrej wiary jest również instrumentem rozłożenia ryzyka pomiędzy odliczającym a organem na zasadzie proporcjonalności. $\mathrm{Z}$ tego wynika również, że zadania stawiane przed podatnikiem oraz organami podatkowymi powinny mieć charakter rozłączny — nie można oczekiwać podjęcia działań, które wykraczają poza możliwości poznawcze podatnika ${ }^{6}$. Niedopuszczalna jest również sytuacja, w której tak szeroko pojmowane obowiązki weryfikacyjne podatnika ograniczają zakres kompetencji organów podatkowych.

Stawiana przez WSA teza, że weryfikacja kontrahenta powinna być jak najbardziej szczegółowa, rozmija się z przyjętą przez Trybunał zasadą powściągliwości w procesie rekonstrukcji wzorca staranności. Owa ostrożność powinna ucieleśniać w sobie konstytucyjną zasadę demokratycznego państwa prawa oraz zasadę proporcjonalności, która chroni podatnika przed nadmierną ingerencją organów podatkowych. Równie ważne jest zachowanie zasady legalizmu, aby minimalizo-

5 Ibidem, s. 41.

6 Wyrok TSUE z 21 czerwca 2012 r., C-80/11 i C-142/11, Mahagében Kft, Péter Dávid przeciwko Nemzeti Adó- és Vámhivatal Dél-dunántúli Regionális Adó Főigazgatósága, Nemzeti Adó- és Vámhivatal Észak-alföldi Regionális Adó Főigazgatósága. 
wać ryzyko pozbawienia rzetelnego podatnika prawa do odliczenia $\mathrm{VAT}^{7}$. Wzorzec należytej staranności powinien zawierać się w działaniach, które są możliwe do spełnienia w normalnym toku działalności. A contrario, nie można oczekiwać podjęcia takich środków, których nie podjąłby podatnik w kontekście zwyczajowo przyjętych zasad przezorności i sumienności tego rodzaju podmiotów. Nie będzie zatem zasadne oczekiwanie podjęcia jak najbardziej szczegółowej weryfikacji kontrahenta, do której w swojej pierwszej tezie odnosi się WSA.

Zgodnie z ustawą o podatku od towarów i usług każdemu podmiotowi, który spełni warunki formalne, przysługuje prawo do odliczenia podatku VAT naliczonego. Pozbawienie podatnika tego prawa jest sytuacją wyjątkową oraz musi mieć swoje uzasadnienie. Zgodnie z zasadą, że wyjątki stosujemy zawężająco, nie powinny być nakładane na podatnika takie obowiązki w zakresie dochowania należytej staranności, które znacząco uniemożliwiałyby mu skorzystanie z prawa do odliczenia ${ }^{8}$.

Odnosząc się do postawionej przez WSA tezy, warto podkreślić również, że weryfikacja kontrahenta nie jest celem samym w sobie, jaki stawia się podatnikom ${ }^{9}$. Wynika to z rozważań, że organy nie mogą oczekiwać podejmowania przez podatnika czynności sprawdzających, które nie są jego zadaniem. Ponadto podatnik jest zobowiązany do zasięgania informacji o kontrahencie tylko w takiej sytuacji, gdy pomimo zweryfikowania dokumentów rejestracyjnych kontrahenta zaistnieją przesłanki, by podejrzewać nieprawidłowości lub naruszenie prawa. $\mathrm{Z}$ tego jasno wynika, że podatnik nie ma obowiązku kontrolowania swojego kontrahenta, nie można zatem oczekiwać szczegółowej weryfikacji, jaką wskazał WSA w swojej pierwszej tezie.

\section{Brak zainteresowania źródłem pochodzenia towaru}

W uzasadnieniu Sąd odwołuje się do orzecznictwa międzynarodowego, wskazując, iż „z orzecznictwa TSUE wynika [...], że przesłanką wystarczającą do pozbawienia podatnika prawa do odliczenia podatku naliczonego jest nie tylko świadome uczestnictwo w oszustwie podatkowym, ale także brak należytej staranności”. Nie można się nie zgodzić, że wyroki TSUE powinny być brane pod uwagę przy wydawaniu orzeczeń przez sądy krajowe. Równocześnie należy podkreślić, że rolą sądów krajowych jest, aby orzecznictwo TSUE stosowane było w pełni - aby respektowane były wszystkie orzeczenia wydane przez Trybunał, które odnoszą się do sprawy. W glosowanym wyroku WSA powołał się na ukształtowaną linię orzeczniczą, jednak nie została ona zastosowana podczas określania

7 Wyrok TK z 9 stycznia 1996 r., K 18/95.

8 Wyrok TSUE z 11 maja 2006 r., C-384/04, Commissioners of Customs \& Excise, Attorney General przeciwko Federation of Technological Industries $\mathrm{i}$ in.

9 Wyrok TSUE z 6 września 2012 r., C-324/11, Gábor Tóth przeciwko Nemzeti Adó- és Vámhivatal Észak-magyarországi Regionális Adó Főigazgatósága. 
terminu „należyta staranność”. W szczególności chodzi o uznanie braku zainteresowania przez podatnika źródłem pochodzenia towaru jako przesłankę pozwalającą na założenie, że nie dochował on należytej staranności. W uzasadnieniu Sąd wskazuje, że ,od standardów odbiegał [...] sposób weryfikacji kontrahentów”, a następnie dodaje, że ,poza kręgiem jej [spółki] zainteresowań pozostawało źródło pochodzenia towaru, jego przeznaczenie”. Odmienny pogląd reprezentuje WSA w Gdańsku, który w swoim orzeczeniu przyznał, że podatnik dochował należytej staranności poprzez wykorzystanie wszystkich przyznanych prawem możliwości w zakresie sprawdzenia kontrahentów — między innymi sprawdzenie w rejestrze przedsiębiorców KRS, sprawdzenie statusu jako czynnego podatnika VAT oraz zweryfikowanie numerów NIP i REGON. Ponadto Sąd podkreślił, że brakuje przepisów, które nakładałyby na podatnika obowiązek dokonania innych czynności ${ }^{10}$. Warto dodać, że jest to wyrok wydany tuż po wyroku TSUE C-277/14 z 22 października 2015 roku, a więc implementujący wskazówki do polskiej praktyki kształtującej się bezpośrednio pod wpływem bieżącego orzecznictwa Trybunału ${ }^{11}$. Niewątpliwie standardem nie jest oczekiwanie stawiane podatnikowi, że powinien on sprawdzać pochodzenie towaru swojego kontrahenta.

Nie jest to jedyne orzeczenie, które odnosi się do obowiązków podatnika w związku z weryfikacją podmiotu, z którym podatnik zawiera transakcje. Jak już wskazano, zakres działań dotyczących weryfikacji kontrahenta, jaki nakładany jest na podatnika, nie może wchodzić w zakres obowiązków organów podatkowych. W wykształconej linii orzeczniczej wskazuje się również na konkretne działania, które nie mogą decydować o niedołożeniu należytej staranności przez podatnika. Za jedno z takich działań uważa się zbadanie, czy wystawca faktury faktycznie dysponuje danymi towarami oraz czy jest w stanie je dostarczyćc ${ }^{12}$. Jeżeli zatem nie ma obowiązku, aby podatnik sprawdził, czy kontrahent dane towary posiada, tym bardziej niezasadne jest przyjęcie, że jest on zobligowany do tego, aby znać źródło ich pochodzenia.

Warto podkreślić, że pod hasłem ,,pochodzenie towaru” kryje się nie tylko bezpośrednia dostawa, lecz także łańcuch transakcji ją poprzedzających. Nie będzie zasadne twierdzenie Sądu, że ,wątpliwości budzi [...] fakt, iż [...] nie interesował się [prezes spółki] nie tylko pochodzeniem przedmiotowego oleju rzepakowego, ale także nie posiadał żadnej wiedzy o tym, na jakie cele ów olej został przeznaczony przez ostatecznego odbiorcę". Do określenia dołożenia lub niedołożenia należytej staranności przez podatnika pod uwagę powinna być brana tylko transakcja stanowiąca bezpośrednią dostawę. Odebranie prawa do odliczenia podatku może nastąpić tylko w sytuacji, gdy podmiot działający na wcześniejszym etapie

\footnotetext{
10 Wyrok I SA/Gd 1192/15.

11 W. Kotowski, op. cit., s. 64.

12 Wyrok TSUE z 21 czerwca 2012 r., C-80/11 i C-142/11, Mahageben kft i in., pkt 61.
} 
obrotu dopuścił się nieprawidłowości ${ }^{13}$. Jak wskazuje się w orzecznictwie TSUE, tylko okoliczności, które wystąpiły w momencie dostawy, mogą decydować o dołożeniu należytej staranności przez podatnika ${ }^{14}$. Z przedstawionych rozważań Trybunału wynika jednoznacznie, że prawo podatnika do odliczenia podatku naliczonego VAT nie może ucierpieć wskutek tego, że w łańcuchu dostaw, którego część stanowią dokonane przez niego transakcje, inna transakcja — wcześniejsza lub późniejsza w stosunku do tej, która została przez niego dokonana - stanowi oszustwo w zakresie podatku VAT ${ }^{15}$. Po konfrontacji przyjętej przez TSUE linii orzeczniczej, nieistotne wydają się ustalenia WSA w zakresie braku wiedzy podatnika o ostatecznym przeznaczeniu przedmiotu transakcji. Nie zasługuje na aprobatę przyjęcie przez Sąd założenia, że podatnik odpowiada za działania, które mogły mieć charakter oszukańczy, ale popełniły je podmioty na poprzednich etapach obrotu towarem ${ }^{16}$. Warto również zwrócić uwagę na pogląd TSUE w wypadku, gdy doszło do nieprawidłowości po stronie dostawcy. Zakłada on bowiem, że nawet jeżeli podmiot bezpośrednio dostarczający towar okazałby się nierzetelny, nie można z góry zakładać złej wiary podatnika. Przeciwnie — najistotniejszym faktem jest samo dokonanie dostawy, co stanowi wystarczającą podstawę do badania dołożenia lub niedołożenia należytej staranności ${ }^{17}$.

\section{Podsumowanie}

Badanie dobrej wiary podatnika podczas weryfikacji kontrahenta należy zawsze przeprowadzać w sposób obiektywny, to znaczy na podstawie ustalonych reguł, które odpowiadałyby wszystkim rodzajom działalności gospodarczej. Ustalenie wzorca należytej staranności powinno gwarantować pewność prawa i tym samym nie naruszać zaufania podatników. Jednym z problemów obecnego systemu podatkowego jest bardzo niejednolita linia orzecznicza polskich organów podatkowych oraz sądów administracyjnych w tym zakresie. Wniosek de lege ferenda może stanowić postulat wprowadzenia terminu, który usystematyzowałby przesłanki przyznające i odbierające podatnikowi status dopełnienia należytej staranności, opierający się na realnie możliwych do podjęcia działaniach.

13 Wyrok TSUE z 21 czerwca 2012 r., C-80/11 i C-142/11, Mahageben kft i in., pkt 49.

14 Wyrok TSUE z 11 maja 2006 r., C-384/04, Commissioners of Customs \& Excise, Attorney General, pkt 31.

15 W. Kotowski, op. cit., s. 45 .

16 Wyrok NSA z 18 grudnia 2012 r. - I FSK 1694/11.

17 M. Szubiakowski, Faktura wystawiona przez podmiot nieistniejacy a prawo do odliczenia w podatku VAT, „Glosa” 2016, nr 2. 


\section{Bibliografia}

Kotowski W. et al., Przestępstwa karuzelowe i inne oszustwa w VAT, red. nauk. I. Ożóg, Warszawa 2017.

Szubiakowski M., Faktura wystawiona przez podmiot nieistniejacy a prawo do odliczenia w podatku VAT, „Glosa” 2016, nr 2.

Zalasiński A., Koncepcja nadużycia podatkowego w unijnym prawie podatkowym - potencjalne kierunki oddziaływania na prawo polskie, [w:] 5 lat doświadczeń w polskim prawie finansowym, red. H. Litwińczuk, Warszawa 2010.

\section{Orzecznictwo}

Wyrok TSUE z 21 czerwca 2012 r., C-80/11 i C-142/11, Mahageben kft i in.

Wyrok TSUE z 11 maja 2006 r., C-384/04, Commissioners of Customs \& Excise, Attorney General przeciwko Federation of Technological Industries $i$ in.

Wyrok TSUE z 6 września 2012 r., C-324/11 Gabor Toth.

Wyrok TK z 9 stycznia 1996 r., K 18/95.

Wyrok NSA z 18 grudnia 2012 r. — I FSK 1694/11.

Wyrok I SA/Gd 1192/15.

Wyrok I SA/Op 428/16.

Wyrok TSUE z 22 listopada 2015 r., C-277/14 PPUH Stehcemp sp.j. Florian Stefanek, Janina Stefanek, Jarosław Stefanek przeciwko Dyrektorowi Izby Skarbowej w Łodzi.

\section{Lack of interest in the origin of the goods as a premise undermining the due diligence of the taxpayer - commentary on the verdict of the Provincial Administrative Court, seat in Opole, of 27th January 2017, on the signature I SA/Op 428/16}

\section{Summary}

The examination of the taxpayer's good faith during the verification of the contractor should always take place in an objective manner, i.e. on the basis of established rules that would correspond to all types of business activities. Establishing a due diligence standard should guarantee legal certainty and thus not infringe taxpayers' trust. One of the problems of the current tax system is the very heterogeneous judicial line of Polish tax authorities and administrative courts in this regard. The de lege ferenda proposal may constitute a postulate of introducing a term that would systematize the premises granting and taking away the taxpayer's status of due diligence, which will be based on realistically possible actions. 